Article

\title{
City-Region Food Systems and Second Tier Cities: From Garden Cities to Garden Regions
}

\author{
Koen van der Gaast ${ }^{1,2, * \mathbb{C}}$, Eveline van Leeuwen ${ }^{1}$ and Sigrid Wertheim-Heck ${ }^{1,2}$ \\ 1 Wageningen University, 6700-6709 Wageningen, The Netherlands; eveline.vanleeuwen@wur.nl (E.v.L.); \\ sigrid.wertheim-heck@wur.nl (S.W.-H.) \\ 2 Aeres University of Applied Sciences Almere, Stadhuisstraat 18, 1315 HC Almere, The Netherlands \\ * Correspondence: koen.vandergaast@wur.nl
}

Received: 25 February 2020; Accepted: 19 March 2020; Published: 24 March 2020

\begin{abstract}
Theory and practice show that second-tier cities can play an important role in linking the urban and the rural. Second-tier cities are the middle ground of the urban system. The smaller spatial scale of second-tier cities, and their often-stronger connections with the rural hinterland can potentially enable a more sustainable food system. In this paper, we argue that the extent to which the benefits ascribed to the re-localisation of food can be achieved greatly depends on the contextual specifics of the second-tier city and the region in which it is embedded. Furthermore, we argue that to reach resilient, healthy and environmentally friendly city region food systems, three contextual elements need to be considered in their mutual coherence: (1) the historical development of the second-tier city and the region; (2) the proximity of food production to the second-tier city; (3) the scale and reach of the city region's food system. We use the case-study of the Dutch city Almere to show how (a controlled) growth of cities can be combined with maintaining (or even increasing) the strength of adjacent rural areas. Such cities can play a role in creating Garden Regions: regions that foster healthy, sustainable and resilient food systems and that do not just connect urban and rural regions, but also connect city region food systems to national and global markets.
\end{abstract}

Keywords: city-region food systems; second tier cities; Garden Regions; Almere

\section{Introduction}

Cities are increasingly taking the lead in the food system transition with a focus on city-region-based food provision [1,2]. This trend is motivated by reasons of resilience, health and environment. Firstly, there is belief in the importance of reducing the dependency on international trade. Establishing a more direct link with the agricultural hinterland is regarded as a resilience strategy in mitigating global food security risks resulting from international trade barriers, natural disasters and climate change, a scarcity of natural resources, and environmental disasters which may lead to price increases and shortages. Secondly, the rising burden of non-communicable diseases (NCDs) is urging drastic food system interventions to improve the dietary intake of citizens for increased wellbeing and reduced healthcare costs [3]. A more regionally oriented food supply is argued to reconnect consumption and production, resulting in the re-valuation and increased uptake of whole foods in urban diets, providing a counterweight to the consumption of ultra-processed foods. Furthermore, city region food systems (CRFS) are motivated by environmental considerations. Shorter supply chains are associated with a reduction in carbon emissions-reduced resource-intensive processing and transportation-and more sustainable production methods [4]. In short, the transformation to more resilient, healthy and sustainable food systems is, to a large extent, sought in regional production, shorter supply chains, and more conscious food consumption. Localised, and specifically plant-based, whole food diets 
are argued to offer health benefits, to reduce greenhouse gas emissions and biodiversity loss, and to stimulate local economies [5-12].

One fruitful avenue for urban-rural (re-)connections is through second-tier cities. Second-tier cities are the middle ground of the urban system. The smaller spatial scale of second-tier cities, and their often-stronger connections with the rural hinterland potentially enables a more sustainable food system. This is not a new idea. In the 1970s, governments in developing countries tried to promote the growth of second-tier cities in order to slow rural-urban migration and to spread economic growth over a larger part of the country, not only the primary city [13]. Back then, second-tier cities were seen as tools to enlarge urban-rural interactions by promoting urban-based markets for agricultural goods, and, as such, increase rural development.

However, in current planning, geography and urban/regional economics, the focus is directed primarily on urban agglomerations and benefits arising from large consumer markets, a diverse labour-market pool and short distances between firms and their ideas [14]. Concerning the relationship of the city with food, even though this relationship is at the core of much of the theoretical insights that both spatial economists and planners build upon, somehow it has gone out of sight, and therefore out of heart. Due to scale enlargement and globalisation in the agricultural sector, the dynamic relationship between food and cities not only has become invisible, but, in some cases, is also untraceable. Therefore, this paper explores the relationship of second-tier cities with food in theory and practice to understand its role in developing City Region Food Systems. Furthermore, we assess the extent to which the benefits ascribed to the re-localisation of food can be achieved when considering the contextual specifics of the second-tier city and the region in which it is embedded. Based on theory and practice, we argue that to reach resilient, healthy and environmentally friendly city region food systems, three contextual elements need to be considered in their mutual coherence:

(1) The historical development of the second-tier city and the region;

(2) The proximity of food production to the second tier city;

(3) The scale and reach of the city region food system.

This paper examines the three key elements related to the potential of second-tier cities in the urban-rural reconnection, with the Dutch city of Almere as an illustrative case. Almere is a city of 42 years old, with over 200,000 inhabitants. Originally, it was developed as an overflow area for Amsterdam: since the housing demand in Amsterdam was bigger than the supply, housing prices in Amsterdam were too high for most young households and they chose to buy a house in nearby municipalities, including Almere. Originally, 70-80 percent of the housing stock consisted of public housing. Still, today, the traces of the youthfulness of Almere are apparent: her population is relatively young and multicultural [15]. At the same time, Almere was designed according to the principles of the Garden City of Ebenezer Howard: a vision in which second-tier cities such as Almere would be embedded in their agricultural hinterland. In practice it did not work out as planned, partly because the wider region of Flevoland developed into an intensive, export-driven agricultural hotspot. However, recently, the city of Almere aimed to change this by setting very ambitious goals in terms of sustainable food. The city aims to obtain $20 \%$ of her food from within the region's boundaries in 2022 . This makes the city a very relevant case.

In this contribution, first, theory and practice concerning second-tier cities and food will be discussed based on a literature review. Second, the three aforementioned contextual elements, as abstracted from theory and practice, will be discussed in relation to the case study of Almere as a second-tier city within the agricultural hinterland of Flevoland. Third, this paper will conclude with stating that, to achieve CRFS, second-tier cities should not aim to become self-sufficient Garden Cities, but Garden Regions that connect to other regions, as well as to the national and global market. 


\section{Food and Second-Tier Cities in the Theory of Urban and Regional Economics}

In every country, a hierarchy of cities is present. Nevertheless, the extent to which larger cities tower over the small ones differs from case to case. In countries like Indonesia, France and England, there is one clearly dominant primate city. However, in some countries, for example the USA, Brazil and China, we see more than one primate city, resulting in the absence of a single dominant city. Furthermore, in some countries, the primate cities are not necessarily very large, as is the case in Malaysia and New Zealand. In contrast, Kuala Lumpur and Auckland do show some primate city features in the sense that they generate a disproportional percentage of a nation's Gross Domestic Product (GDP) [16]. 'Second-tier' cities exist next to primate cities. According to Rondinelli [13], second-tier cities 'usually ranged in size from approximately 100.000 in population to the second largest city in a country' (p. 42), a threshold that is still in use today. Increasingly, these second-tier cities are seen as important tools in leading sustainable economic and social development $[17,18]$, for example, because they can develop a high level of social capital which allows them to effectively mobilize at scale [16].

As far as food and cities are concerned, most of the very first cities in history were founded in fertile agricultural areas where it was relatively easy to feed citizens, in other words, non-farmers. When thinking about the systems of cities, one cannot avoid taking into account urban-urban as well as urban-rural relationships. Within the urban and regional economics literature, a city often started with a market in which (rural) products were sold. Von Thunen [19] explained the monocentric circles of land-use surrounding urban settlements by transport costs and the market price of a certain product: strawberries were produced closest to the city, while preservable and easy to transport products like beans, wheat and wood were produced in the outskirts of the region. In this monocentric city model, each farmer wants to be as close to the city as possible, resulting in higher land-rents near the market. Weber [20] elaborated on this line of thinking by optimising the location and size of manufacturing firms.

A few decades later, Christaller [21] and Losch [22] moved away from the monocentric city and tried to differentiate between cities based on the functions they have [23]. This is also referred to as the 'Central Place Theory'. In this theory, identical consumers in a homogenous region accommodate a hierarchy of locations, in which different types of products are offered. The hierarchy exists because of internal increasing returns to scale at the city level, as well as the transport costs of individual consumers. In lower ranked settlements, only everyday products like bread are provided, since (daily) transport costs prevail. For items that consumers buy less often, like jewelry or electronics, internal increasing returns to scale are more important, and those services can only be provided in the central city, with enough (potential) customers that do not mind the occasional extra transport costs. As such, it has to do with market potential. The final result is a region with a central place in which all services are offered, smaller cities in which part of the services are offered, and villages in which mostly everyday services/products are provided Central Place Theory is not a causal, but a descriptive story. However, it evoked a powerful image that was used to design the settlement structure of the oldest part of Flevoland, the 'Noord-Oost Polder', in 1946.

Not only urban and regional economists looked at hierarchies of cities, planners did so as well. One notable example in the context of this paper is Ebenezer Howard [24], who published the book "Garden Cities of To-morrow" in 1898. He developed a system of smaller and larger cities that benefited from each other, and the services they would offer in terms of amusement, job opportunities and higher wages (urban benefits), as well as fresh air, fresh food and low rents (rural benefits). In his view (and time-frame), the optimal size of the central city was 58,000 persons, and the ring of second-tier 'garden' cities would house 32,000 persons. The second-tier cities were connected by a railway, and located near the central city, agricultural land and allotment areas. The total population of the system of central and second-tier 'garden cities' was self-sufficient in terms of food, ecosystem services and jobs, and hosted 250,000 persons. This concept has been applied in at least two British cities, as well as in the original plans of the Dutch city of Almere. 
Parallel to these theories that depict cities as being linked to their surrounding 'hinterland', theories that support a disconnect were used as well. This started with Adam Smith in the eighteenth century, who claimed that the urban economy could only grow by exporting products to a region further away. This notion was elaborated by Sombart [25], who developed the export-base theory: most important goal for a local economy is to bring in foreign (regional) currency by exporting as much and importing as little as possible. This allows not only the exporting activities to grow, but also local non-basic businesses such as services, health and education. Ricardo also strongly emphasised trade and comparative advantages: regions should specialise in products or services that they are good at producing and trade these for other products that they need [26]. This notion was advanced by Porter in 'The competitive advantage of nations' [27]. His intuition is still very much used in current policy- and decision-making. The increasing tendency of focusing on (regional) economic growth by minimizing costs and maximizing export and specialisation resulted in the globalisation of many production systems, not the least the globalisation of food systems. It has loosened the link and increased the distance between production and consumption [28], between urban and rural areas.

Although urban-rural interactions are often thought to be less important today, this is not the case. Of course, some of the interactions became less local, and hence less visible [29]. Unfortunately, this also resulted in the diminished interest of researchers in urban-rural interactions, not least in terms of agricultural activities and food [30,31]. This is unfortunate, since we know urban-rural interactions can be beneficial to both types of areas, and result in higher levels of (sustainable) growth of both [30,32]. In order to facilitate a sustainable food system transition, we need to take on board urban-rural interactions at different spatial levels to evaluate both the environmental and economic benefits to the system as a whole, as well as to individual regions.

\section{Food and (Second-Tier) Cities in Practice}

The Netherlands provides an illustrative case of how urban-rural relations have developed over time. Historically, the Netherlands developed as a polycentric system dominated by several second-tier cities. Most early cities arose in places where trade flows came together, or where the seat of power was located. Since 1400, (almost) no new cities emerged. The established ones had equal sizes, resulting in a polycentric urban hierarchy [33]. In the 16th century, many small cities increased in size due to decreasing agricultural production in the countryside. This resulted in migration flows from rural to urban areas and a large number of urban workers willing to accept very low wages. This strengthened the foundation for the current Dutch polycentric system.

However, urbanisation was accelerated almost exponentially due to the industrial revolution, which was preceded by an agricultural and transport revolution. Agricultural innovations led to agricultural production intensification, enabling a decoupling of urban and rural development. Cities, but sometimes also villages, grew enormously into the so-called industrial cities. Examples are Enschede, Eindhoven, Heerlen and Helmond in the Netherlands (similar to the well-known examples of Liverpool, Leeds and Birmingham in England). The population in Amsterdam and Rotterdam also grew by 100,000 persons per decade. However, agriculture and urban development remained closely linked. Up until the mid-20th century, cities large and small were heavily dependent on their agricultural hinterland for their food security.

This changed during the second half of the 20th century, when economic globalisation and a comfortable condition of food abundance allowed a rural urban disconnect, in which rural areas were characterised by large-scale, highly efficient and export-oriented food production. These developments were enforced by the Common Agricultural Policy initiated after the two World Wars. Functionality was the dogma in the Dutch planning system [34], in which an extensive set of regulations aimed at protecting open space and maintaining an urban-rural divide [35]. Rural planning focused on agricultural production, while urban planning paid little attention to food systems, emphasising urban priorities such as industrial development, public transportation and housing. 
In recent decades, Dutch planning policies are changing from a top-down urban-rural segregation approach towards more decentralised and integrative planning systems. It has shaped regional development initiatives in which the integration of area-specific characteristics and local stakeholders are becoming increasingly important [36]. Food system transitions play an important role in this reform. The contemporary globalised food system is under criticism due to its multiple negative sustainability impacts on society and the environment. Systemic changes are required to meet the needs of future generations in a sustainable way [37]. The (re)localisation or regionalisation of food systems is a trend that is often presented as an alternative to the 'globalised' food system and its presumed unsustainability [1,38]. A growing group of cities, many being signatory cities of the Milan Urban Food Policy Pact (MUFPP) feels responsible for the healthy and sustainable feeding of urban populations [39]. Food systems thinking is increasingly becoming incorporated into the planning of urban areas, and a trend is observed in which cities embrace a CRFS orientation, thus seeking the re-establishment of the historical reconnection between agriculture and urban development on a regional scale.

Buchan et al. [40] argue that local food systems offer an important sustainable opportunity and are an essential part of any community's sustainability and resilience strategy. Not everyone agrees with this. For example, Edwards-Jones [8] states that there is no evidence that local food is universally superior to non-local food in terms of its impact on the climate or the health of consumers. Born and Purcell [41] even refer to a 'local trap', i.e., using a default assumption that the local scale is always preferable to other scales. However, in addition to the sustainability and health considerations, city-region-food systems are motivated by reducing dependence on international trade. In order to cope with the effects of climate change and serious natural disasters, as well as trade barriers and wars, resilience, or resilience planning, is becoming an explicit part of urban and regional policy. Besides climatic uncertainties, it is likely that the coming decades will be characterised by geopolitical and economic uncertainties. CRFS is considered an important strategy in mitigating uncontrollable disturbances in the international food system.

\section{The Second-Tier City of Almere}

The previous chapter shows that the proximity of cities to food production has changed back and forth throughout history, both in theory and practice. The current trend of CRFS seems to bring back the theoretical and practical history of the agricultural hinterland as central to urban development. However, it also shows that reconnecting the urban and the region is not necessarily always beneficial in terms of sustainability. To avoid the local trap, the ideal scale and reach of the CRFS to other regions, nationally and globally, needs to be critically assessed. Being a signatory city of the MUFPP and a leading city in the Dutch City Deal, Almere is a relevant case as a second-tier city in a city-region food system transition. Below, we assess the re-localisation of Almere's food system orientation along the aforementioned three contextual elements of (i) the historical development of the city and the region, (ii) the proximity of the second-tier city and food production and (iii) the scale and reach of the city-region food system. This chapter will be concluded with a detailed discussion of two different local food experiments in Almere Hout and Almere Buitenvaart in regards to these three contextual elements.

\subsection{Historical Development: Two Different Development Pathways of Almere and Flevoland}

Established in 1975, Almere is the youngest city of The Netherlands. Despite its age, the city has rapidly developed into the seventh largest municipality of the Netherlands with over 200,000 inhabitants (compared to Amsterdam with over 850,000) and its growth seems to be continuing. It is expected that Almere will grow to more than 270,000 inhabitants in the year 2040 and will surpass 300,000 in 2050 [42]. It is the largest municipality in the province of Flevoland: an area of land reclaimed from the sea in the 1960s and designated for agricultural production [43]. Almere was designed as a polynuclear Garden City, inspired by the aforementioned Ebenezer Howard's concept, with the 
idea of anchoring the relationship between its residents, nature and food production [44]. In practice however, this ideal was never achieved.

The development pathway of Flevoland was quite different. It was created in the context of "never hunger again" after World War I and II. The land was set up for large-scale agriculture and intensive cultivation systems with a strong export orientation. Due to the favorable agro-ecological conditions and advanced farming practices, Flevoland is now one of the most productive agricultural areas in the world. It is a major player in the global food system and the agricultural sector is characterised by highly productive, export-oriented concentration with better connections to the port of Rotterdam than the provincial cities. There are 1755 agricultural producers in Flevoland, of which over $60 \%$ grow vegetable $[45,46]$. For the major crops-like onion, potato, carrot—-the yields per acre in Flevoland are among the highest in the world. Most of the production is designated for export. The Netherlands is one of the world's largest exporters for these products.

In a later stage, and with a different political agenda, urban centers such as Lelystad and Almere were created in Flevoland to accommodate population growth, in particular as an overflow area for Amsterdam. As a consequence, two separate worlds have emerged in Flevoland, cities and agricultural hinterland. The cities, with Almere at the forefront, are successful in their own right. They have the largest population and associated economic growth in the Netherlands [42]. Not only was Almere the fastest growing municipality in the Netherlands, for the last twenty years it was also one of the four most culturally diverse cities of The Netherlands. Almere accommodates 148 nationalities [47]. Only $18 \%$ of citizens were born in Almere and over $41 \%$ have a migrant background; $30 \%$ of the population has a non-western migrant background and their share is increasing.

Between the two developmental paths of city and region, a tension can be observed. Due to the rapid population growth, a growing and diversifying urban appetite emerged. In the context of majority-minority cities [48] such as Almere, production diversification is required to meet the varying diet of the urban population. At the same time, the agricultural hinterland is still characterised by a large-scale concentration for export markets. With the production of the top three crops, onion, potato and carrot, Flevoland could, in theory, easily supply the entire Almere population; for instance, $3.2 \%$ of the consumption potatoes grown in Flevoland in a year could feed Almere for a year. The production of other vegetable crops, like spinach, turnip and kale, allows potential for diversification in the locally sourced menu. However, this is hardly diverse enough to meet the diet of a multicultural urban population. Moreover, it is questionable whether Flevoland can keep up this model of agriculture in the long-term in a sustainable way. Climate change, soil degradation and spatial competition with other non-agricultural destinations, like solar energy parks, urban expansion, infrastructure and business districts, will result in a concomitant decline in arable land and its productivity, while land prices are rising [46]. Furthermore, with the rise in seawater level, the costs of the conservation of Flevoland will increase. This shows that the agricultural regions need cities to maintain their agricultural destination. With a strong, export-oriented sector, the question is, therefore, to what extent Dutch residents, through taxes, are willing to pay to maintain arable land for export cultivation. Meanwhile, exports are also under increasing pressure, due to increased uncertainty in international trade relations, climate change and the development of emerging countries as production areas [49]. All these developments incentivise a reflection on the current sector orientation and organization, towards a more regional-oriented food system.

\subsection{Proximity of Agro-food Production to Almere as a Second-Tier City}

While an urban-rural reconnaissance is not unique to Almere-other cities are also increasingly focusing on regional food systems-there exist favorable conditions in Almere and Flevoland for the transition to a city region food system. As already mentioned, the city of Almere has an explicit urban food policy with the target of meeting $20 \%$ of Almere's food consumption with regional production by 2022 [50]. This is not accidental. While urban agriculture in Almere never took off as originally envisioned, agriculture has, since its creation, remained an important pillar in the sustainability policy 
of the municipality of Almere, and its overall vision for the future. With the International Horticultural Exhibition 'Floriade' coming up in 2022, it is currently Almere's explicit ambition to show that cities themselves can produce healthy food for their residents in a sustainable way.

There are several reasons for Almere to reinvigorate its relationship with its agricultural hinterland. Firstly, a renewed regional urban-rural interdependence is expected to increase with the advancement towards more circular food systems [51] For example, soil fertility on land will become increasingly dependent on the recovery of nutrients and organic material from urban waste streams [45]. Moreover, strengthening the regional urban-rural food connection is considered important in restoring societal confidence in food quality. The increasing distance between production and consumption, and the increasing complexity of the global food system, have led to a kind of food alienation and eroded societal confidence in the global food system.

Fewer and fewer consumers know where the food they consume comes from, how it was produced, or what the exact ingredients are. Reducing the physical and psychological distance between consumers and food producers is considered instrumental in re-establishing trust in food. The proximity of agro-food production to the city is also embraced as a fruitful avenue for making the urban diet healthier. More than half of the Almere population is suffering from lifestyle and dietary-related non communicable diseases [52]. A more regionally oriented food system is supposed to make a positive contribution to healthy food consumption lifestyles, based on the assumption that a more direct connection of consumption with production contributes to increasing the appreciation, and thereby the consumption, of unprocessed fresh food, countering the increasing consumption of unhealthy processed foods [1].

It is important to note that attempts to integrate city and region are not carried out through top-down government, but through governance in which a plurality of actors play a role. In general, in studies of food, the system of food provision often overshadows the broader dynamics of everyday consumption. The food choices that city dwellers make are crucial in the transition to a healthier and more sustainable food system. These choices depend on what the environment has to offer, but the food cultures, tastes and preferences of city dwellers are equally important. In short, consumers co-shape the food environment. Almere, being a migrant city, provides ample evidence of this. For instance, the food consumption practices of Syrian migrants demonstrate the reciprocal relation between cultural habits and the food environment [53]. These migrants even established connections with local food producers, like dairy farmers, to accommodate their cultural dietary preferences of Syrian fresh cheese. Due to the increasing multi-ethnic composition of populations in cities, Almere demonstrates an interesting dynamic between the food environment and cultural food practices, in advancing towards city-region food systems. Developing a peri-urban interface is considered supportive of these means. Almere is experimenting with blurring the spatial and functional urban-rural relationship through the 'peri-urbanisation' project Oosterwold [54], in which urban expansion is combined with food production. Urban and peri-urban farming in Oosterwold is approached as an alternative route for achieving a more sustainable and healthier urban food system.

\subsection{The Scale and Reach of the City-Region Food System}

A more regional oriented urban system thus has added value, but it is not productive when "local food" turns into an undisputed dogma [55]. First of all, both regional and local are ambiguous terms and their boundaries are not unequivocal [12]. The definition of 'local food' appears to be subject to different interpretations and, as such, can be considered a flexible concept. The most commonly used definitions are based on geographical distance or regional origin, often defined on the basis of planning classifications such as 'provincial'. Since regional food systems intersect with other regions as well as the national and global food system, it is hard to classify a food product as regional or local. Cheese for instance, produced according to a certain local recipe, is not completely local when the cows are fed soy that is imported from Brazil. Onions from Flevoland are often netted in the province Zeeland in the south of The Netherlands. 
Secondly, we would like to highlight the tension of Almere-Flevoland's regional reorientation and Flevoland's global responsibility. As discussed before, Almere has a diverse cultural population and therefore demands a great diversity in fresh products. This variation is currently not provided for in the highly efficient large-scale agro-food sector of Flevoland. Crop diversity is mainly limited to foods, such as carrots, onions and potatoes, that can be made into traditional Dutch meals but don't meet the appetite of an increasingly diverse urban population. Integrating the food demand of Almere with production in Flevoland requires alterations to the production system. At the same time, Flevoland now is one of the most efficient agricultural food production regions of the world. The current export-oriented agri-food sector is important for the economy of Flevoland and The Netherlands as a whole [46]. They have a broader responsibility than feeding nearby cities. They also have a responsibility as an agro-food producing region for the Metropole Region Amsterdam (MRA) [56], the whole of the Netherlands, Europe and the world.

The search for such a balance is reflected in the Almere municipal and Flevoland provincial collaboration in versatile networks, like (1) City Deal, in which cities exchange experiences with new forms of urban food policy and (peri-urban) agriculture; (2) FlevoFood which is a network association of Flevoland food companies aimed at stimulating the consumption and production of food products with provincial orientation; (3) VoedselVerbindt (FoodConnects), a regional platform that is committed to a sustainable, regional and circular food system with a wider metropolitan orientation to provinces, Noord-Holland and Flevoland and, importantly, the cities of Amsterdam, Almere and Zaanstad; (4) Agro Expert Raad Flevoland (Agro Expert Council Flevoland), an independent advisory body that investigates the future potential of the Agrofood sector of Flevoland in the transition to sustainable food security, taking into account local, regional, national and international perspectives.

\section{Two Local Food Experiments: Almere Buitenvaart and Almere Hout}

To further illustrate the salience of history, proximity, scale and reach, to understand how second-tier cities as Almere can help to create sustainable, healthy and resilient CRFS, it can be instructive to hone into two different attempts to bring food production closer to the city.

The history of Almere Buitenvaart, in the north-eastern part of Almere, fits more in the development path of Flevoland. Buitenvaart was assigned to greenhouse horticulturists that were relocated from different parts of the Netherlands, mostly Amsterdam. They grew flowers for the global market. They were very successful in the beginning but due to the availability of cheap flowers from emerging markets many horticulturists went bankrupt over time.

Therefore, many horticulturists have left or changed their business model. Some started non-horticultural economic activities, such as caravan storage, to survive economically. Inspired by the municipal policy of Feeding the City, of producing food in the city, the municipality stimulated horticulturists to make the change from flowers to vegetable production. However, this aim to increase the proximity of food production and the city imposes severe challenges. The isolated area in which they were operating (see Figure 1) constrained the finding of business partners in the agricultural hinterland of Flevoland and connections to the market in Almere. Only a few have made the change successfully to date. The care-farm Weet Hoe Je Leeft (know how you live), for example, mixes organic farming with employment opportunities for the (partially) disabled. The farm also incorporates a small shop with local products, and a lunchroom. Another example of a successful transition is ONZE (Our), that offers opportunities for allotment gardening in greenhouses to citizens. 


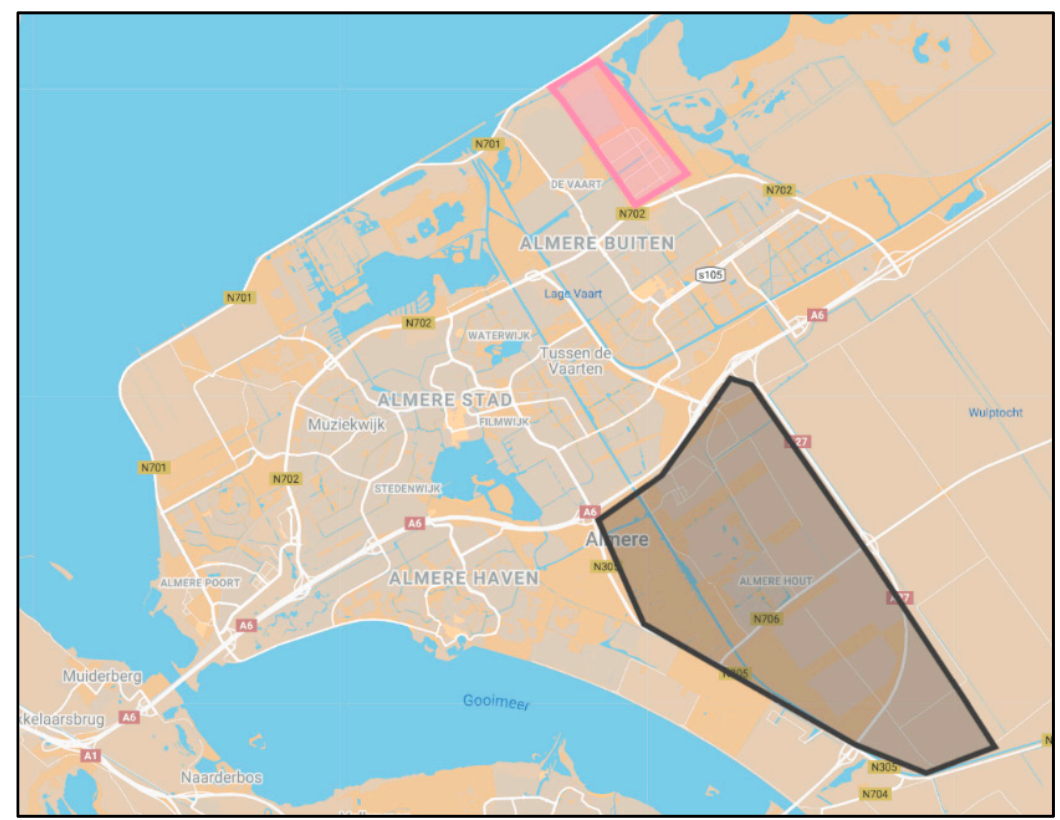

Figure 1. Map of Almere. Almere Buitenvaart is demarcated in red. It is closed off from the rural hinterland because there is a natural park in between (Oosvaardersplassen; east). An industrial belt (De Vaart; west) separates it from the residential areas. Almere Hout is demarcated in black. Close to other regions (in the south), close to agricultural hinterland of Flevoland (east) and residential areas (north and west). Source: Google Maps (own demarcations).

The history of Almere Hout on the other hand illustrates the attempt to, in line with the Garden City design, link the urban population to a green environment. The Kemphaan, one of the parks that were designed for citizens to experience nature, hosts several educational programs for schools in Almere. In this area, the aim to increase the proximity of food to the city was more successful. Urban agriculture emerged in the late 1990s, when de Stadsboerderij (Urban Farm) moved from their plot in the western part of town to the area near the urban park The Kemphaan. De Stadsboerderij is an organic farm with crops and cattle. In order to get more support from the municipality and to be allowed a permanent place in the city, de Stadsboerderij had to organise itself through a foundation: Vrienden van de Stadsboerderij (Friends of de Stadsboerderij). Through this foundation, they mobilised support from many different stakeholders and embedded themselves in the city as well as in the agricultural hinterland. De Stadsboerderij does not just bring food closer to the city by producing it, it also hosts a weekly farmers market where urbanites can buy food and rural and urban producers can sell it.

Moreover, through the product label Almeerse Weelde (The wealth of Almere), it organises the small-scale production of jams, sausages, beers, etc. [57]. Furthermore, De Stadsboerderij organises and participates in different educational activities. For instance, they host an educational foundation, Voeten in de Klei, (Feet in the Clay), that teaches school children about food and where it comes from. This relates to the origin of Almere Hout as an area to experience nature and learn about it. Recently de Stadsboerderij started to expand into Almere Oosterwold. This is an area that used to be agricultural land. Now, the municipality of Almere allows residents to build houses there, provided that they use $50 \%$ of the land to produce food. De Stadsboerderij bought a plot of land there and built a new farmhouse.

This also illustrates the reach of de Stadsboerderij to other regions besides Flevoland. Food producers and products from all over Flevoland (e.g., bread from Zeewolde, vegetables from Dronten, wine from Lelystad) can be found on their farmer's market. Not only the participants, but also some of the visitors, are from outside Almere. As far as Almere Buitenvaart is concerned, their reach is more limited. Some of the horticulturalists want to source the Metropolitan Region of Amsterdam (MRA). This would enable them to source a larger market. They asked Food Council MRA, an organization 
that strives towards a sustainable food system in the MRA, to help them, without any concrete results to date. On the other hand, ONZE shows that it is possible for food producers in Almere Buitenvaart to produce on a small scale for a multi-ethnic audience. Moreover, they attract many Surinam producers from nearby neighborhoods, such as Almere Buiten and Almere Centrum and Surinam producers from all over the Netherlands, from cities such as Zaandam and Groningen [58]. The ability of Almere, as a second-tier city, to reach not just its own hinterland, but that of other regions as well, shows the salience of considering Almere not just as a Garden City, but as part of an emerging Garden Region as well (see Table 1).

Table 1. Summary of the empirical case study.

\begin{tabular}{ccc}
\hline Contextual Factors & Almere Buitenvaart & Almere Hout \\
\hline $\begin{array}{c}\text { Historical } \\
\text { Development }\end{array}$ & $\begin{array}{c}\text { Development pathway of Flevoland: } \\
\text { Export oriented horticulture }\end{array}$ & $\begin{array}{c}\text { Development pathway of Almere: } \\
\text { Connecting urban population to a green } \\
\text { environment }\end{array}$ \\
\hline Proximity & $\begin{array}{c}\text { The municipality of Almere stimulates } \\
\text { a transition from flowers to vegetables. } \\
\text { Isolation from city and hinterland is } \\
\text { an obstacle to this transition, with } \\
\text { notable exceptions } \\
\text { (ONZE; Weet Hoe Je Leeft) }\end{array}$ & $\begin{array}{c}\text { Urban agriculture, in the form of De } \\
\text { urban environment because it (1) links to } \\
\text { original goal of the area in terms of green } \\
\text { education (2) mobilized community support } \\
\text { from nearby residents }\end{array}$ \\
\hline $\begin{array}{c}\text { Aim to source Metropolitan Region of } \\
\text { Amsterdam, so far without visible } \\
\text { results. ONZE manages to attract } \\
\text { multi-ethnic urban agriculturalists } \\
\text { from Almere, Flevoland and beyond } \\
\text { (e.g., Zaandam and Groningen). }\end{array}$ & $\begin{array}{c}\text { De Stadsboerderij hosts a weekly farmers } \\
\text { market that connects urban and rural } \\
\text { producers and consumers from Flevoland, but } \\
\text { also from other provinces. De Stadsboerderij } \\
\text { is also currently expanding into Oosterwold, } \\
\text { a former rural area where urban agriculture } \\
\text { and urban dwelling is combined. }\end{array}$ \\
\hline
\end{tabular}

\section{Conclusions}

Theory and practice on second-tier cities show that they can play an important role in linking the urban and the rural. We argue that to reach resilient, healthy and environmentally friendly city region food systems, three contextual elements need to be considered in their mutual coherence: (1) the historical development of the second-tier city and the region; (2) the proximity of food production to the second-tier city; (3) the scale and reach of the city region's food system. Almere is not a typical second-tier city. The city developed separately from the agrarian landscape that surrounds it. Almere emerged in a province that was designated to agriculture, but was itself founded to manage the population overflow of Amsterdam. At the same time, the province of Flevoland developed over time as a site of large-scale industrial and export-oriented agriculture. On the one hand, there is a tension between these two development paths, since the demands of the urban population and the supply of the rural hinterland are not always in sync. On the other hand, the fact that Almere was designed as a Garden City, with a close relation to urban green and agriculture, makes a (re)connection possible.

Almere Hout and Almere Buitenvaart, two different parts of Almere where local food experiments manifest, illustrate this. Located in the same city, they show a different development in terms of proximity to food. This can partly be explained through their different developmental paths. Almere Buitenvaart followed the path of Flevoland, with its export-oriented focus on global markets. Due to economic developments, it lost its relevance, and their isolation from the city as well as the agricultural hinterland became a problem when they attempted to shift towards the production of food. Almere Hout, on the other hand, was designed to bring green to an urban population. Out of this relationship between green and urban citizenship emerged an urban agricultural initiative that connected to urban citizens and rural producers as well as to other regions. The examples of Almere Buitenvaart and Almere Hout show that cities and regions can develop relationships with one another in very diverse ways, even on the small scale of Almere. 
They also demonstrate that strong ties are required, not just between communities in cities and rural areas, but also between regions, such as between the Metropolitan Region of Amsterdam (MRA) and Almere, Flevoland as a city-region food system (CRFS). Only then can the local trap be avoided, and a CRFS with a second-tier city at the core help to foster resilient, sustainable and healthy food systems. Almere was designed as a Garden City. Now, it can play a role in creating Garden Regions: regions that foster healthy, sustainable and resilient food systems and that not just connect urban and rural regions, but also connect city region food systems to national and global markets.

\section{Limitations of This Study and Implications for Other Cities}

This study provided an exploration of how second-tier cities can play a role in the development of sustainable, resilient and healthy CRFSs. The methodological scope of a literature review and a case study does not enable generalizable findings on a global scale. The contextual factors, historical development, proximity, scale and reach, are therefore not strict guidelines to assess CRFs. However, they can inform future studies on the relationship between regions, (second-tier) cities and food. The case of Almere is a rare occurrence in the European context. It does fit a trend that is visible now in emerging countries in Africa and Asia. The expansion of cities in rural areas that emerge out of small city cores show similar dilemmas as those present in Almere. Moreover, in a global context, the urban concentration of a population is common. Moscow, Lagos and Saigon all contain the majority of the population of the country, which poses problems in terms of health and sustainability.

The case of Almere, where green agro-food zones enable a gradient between cities and rural areas, can be an alternative route for these cities. As fertile soil becomes increasingly scarce, the development of urban areas in rural regions should be handled with care. Globally, we can observe a development in which urbanisation increases competition for land in fertile areas. Cities are naturally/historically located in fertile areas, e.g., delta areas, but urbanisation is leading to the expansion of the urban built environment into the countryside and the creation of industrial belts around cities. This is driving competition for land. The expansion of cities, most specifically of megapolises, is, especially in the global south, becoming more problematic. It disconnects production from consumption, and lead-time from shelf-life. The case of a second-tier city such as Almere shows how (a controlled) growth of cities can be combined with maintaining (or even increasing) the strength of adjacent rural areas.

Author Contributions: All authors contributed equally to the paper. K.v.d.G. took the lead in Section 5 and he took care of the final editorial activities; E.v.L. took the lead in Section 2; S.W.-H. took the lead in Sections 3 and 4. The introduction, conclusion and discussion were written together. All authors have read and agreed to the published version of the manuscript.

Funding: This research received no specific external funding.

Acknowledgments: The authors would like to acknowledge the financial support of the Kennisstad (Knowledge City) project of the municipality of Almere.

Conflicts of Interest: The authors declare no conflict of interest.

\section{References}

1. Blay-Palmer, A.; Santini, G.; Dubbeling, M.; Renting, H.; Taguchi, M.; Giordano, T. Validating the City Region Food System Approach: Enacting Inclusive, Transformational City Region Food Systems. Sustainability 2018, 10, 1680. [CrossRef]

2. Dubbeling, M.; Santini, G.; Renting, H.; Taguchi, M.; Lançon, L.; Zuluaga, J.; De Paoli, L.; Rodriguez, A.; Andino, V. Assessing and Planning Sustainable City Region Food Systems: Insights from two Latin American cities. Sustainability 2017, 9, 1455. [CrossRef]

3. ECSKS. EU Burden from Non-Communicable Diseases and Key Risk Factors; European Commission Science and Knowledge Service: Brussels, Belgium, 2018.

4. Blay-Palmer, A.; Renting, H.; Dubbeling, M. City-Region Food Systems: A Review. Understanding the City Region (CRFS) Food System: Planning for a More Food Secure and Resilient City; RUAF: Leusden, The Netherlands, 2015. 
5. Abatekassa, G.; Peterson, H. Market Access for Local Food through the Conventional Food Supply Chain. Int. Food Agribus. Manag. Rev. 2011, 14, 63-82.

6. Bloom, J.; Hinrichs, C. The long reach of lean retailing: Firm embeddedness and Wal-Mart's implementation of local produce sourcing in the US. Environ. Plan. 2017, 49, 168-185. [CrossRef]

7. Brunori, G.; Galli, F.; Barjolle, D.; van Broekhuizen, R.; Colombo, L.; Giampietro, M.; Touzard, J.; Kirwan, J.; Lang, J.; Mathijs, T.; et al. Are Local Food Chains More Sustainable than Global Food Chains? Considerations for Assessment. Sustainability 2016, 8, 449. [CrossRef]

8. Edwards-Jones, G. Does eating local food reduce the environmental impact of food production and enhance consumer health? Proc. Nutr. Soc. 2010, 69, 582-591. [CrossRef]

9. Feldmann, C.; Hamm, U. Consumers' perceptions and preferences for local food: A review. Food Qual. Prefer. 2015, 40, 152-164. [CrossRef]

10. Ostrom, M.; de Master, K.; Noe, E.; Schermer, M. Values-based Food Chains from a Transatlantic Perspective: Exploring a Middle Tier of Agri-food System Development. Int. J. Sociol. Agric. Food 2017, 24, 1-14.

11. Tilman, D.; Clark, M. Global diets link environmental sustainability and human health. Nature 2014, 515, 518-522. [CrossRef]

12. Trivette, S. How local is local? Determining the boundaries of local food in practice. Agric. Hum. Values 2015, 32, 475-490. [CrossRef]

13. Rondinelli, D. Dynamics of growth of secondary cities in developing countries. Geogr. Rev. 1983, 73, $42-57$. [CrossRef]

14. van Leeuwen, E. The rural and peripheral in regional development: An alternative perspective. Reg. Stud. 2019, 53, 924-925. [CrossRef]

15. Tzaninis, Y.; Boterman, W. Beyond the urban-suburban dichotomy: Shifting mobilities and the transformation of suburbia. City 2018, 22, 43-62. [CrossRef]

16. Roberts, M. Managing Systems of Secondary Cities; Cities Alliance/UNOPS: Brussels, Belgium, 2014.

17. Parkinson, M.; Meegan, R.; Karecha, J. City size and economic performance: Is bigger better, small more beautiful or middling marvellous? Eur. Plan. Stud. 2015, 23, 1054-1068. [CrossRef]

18. Camagni, R.; Capello, R. Second-Rank City Dynamics: Theoretical Interpretations behind Their Growth Potentials. Eur. Plan. Stud. 2015, 23, 1041-1053. [CrossRef]

19. Von Thunen, J.H. Der Isolirte Staat in Beziehung auf Landwirschaft und Nationalökonomie; Friedrich Perthes: Hamburg, Germany, 1826.

20. Weber, A. Theory of the Location of Industries; The University of Chicago Press: Chicaco, IL, USA, 1929.

21. Christaller, W. Die Zentralen Orte in Süddeutschland: Eine Ökonomisch-Geographische Untersuchung Über die Gesetzmässigkeit der Verbreitung und Entwicklung der Siedlungen mit Städtischen Funktionen; University Microfilms: Ann Arbor, MI, USA, 1933.

22. Lösch, A. Die Räumliche Ordnung der Wirtschaft; Georg Fischer: Jena, Germany, 1940.

23. Mulligan, G.F. Agglomeration and Central Place Theory: A Review of the Literature. Int. Reg. Sci. Rev. 1984, 9, 1-42. [CrossRef]

24. Howard, E. Garden Cities of To-Morrow; Swann Sonnenschein \& Co.: London, UK, 1902.

25. Sombart, W. Der Begriff der Stadt und das Wesen der Städtebildung. Arch. Soz. Soz. 1907, 25, 1-9.

26. Ricardo, D. On the Principles of Political Economy; Jamal Murray: London, UK, 1821.

27. Porter, M.E. The competitive advantage of nations. Harv. Bus. Rev. 1990, 68, 73-93.

28. Wiskerke, J.S. On places lost and places regained: Reflections on the alternative food geography and sustainable regional development. Int. Plan. Stud. 2009, 14, 369-387. [CrossRef]

29. van Leeuwen, E.S. Urban-rural synergies: An explorative study at the NUTS3 Level. Appl. Spat. Anal. Policy 2015, 8, 273-289. [CrossRef]

30. van Leeuwen, E.S. Urban-Rural Interactions: More Important Than Ever; Wageningen University \& Research: Wageningen, The Netherlands, 2018.

31. van Leeuwen, E.S. Place-based behavior and environmental policies. In A Research Agenda for Environmental Economics; Ruth, M., Ed.; Edward Elgar: Cheltenham, UK, 2020.

32. Dijkstra, L.; Garcilazo, E.; McCann, P. The effects of the global financial crisis on European regions and cities. J. Econ. Geogr. 2015, 15, 935-949. [CrossRef]

33. Rutte, R. Atlas of the Dutch urban landscape. Int. Plan. Hist. Soc. Proc. 2016, 17, 13-26. 
34. Gerrits, L.; Rauws, W.; De Roo, G. Dutch spatial planning policies in transition. Plan. Theory Pract. 2012, 13, 336-341. [CrossRef]

35. Koomen, E.; Dekkers, J.; Van Dijk, T. Open-space preservation in the Netherlands: Planning, practice and prospects. Land Use Policy 2008, 25, 361-377. [CrossRef]

36. Vink, B.; Van der Burg, A. New Dutch spatial planning policy creates space for development. disP Plan. Rev. 2006, 42, 41-49. [CrossRef]

37. Moragues-Faus, F.; Morgan, K. Reframing the foodscape: The emergent world of urban food policy. Environ. Plan. A 2015, 47, 1558-1573. [CrossRef]

38. Forssell, S.; Lankoski, L. The sustainability promise of alternative food networks: An examination through alternative characteristics. Agric. Hum. Values 2015, 32, 63-75. [CrossRef]

39. Morgan, K. Nourishing the city: The rise of the urban food question in the Global North. Urban Stud. 2015, 52, 1379-1394. [CrossRef]

40. Buchan, R.; Cloutier, D.; Friedman, A.; Ostry, A. Local food system planning: The problem, conceptual issues, and policy tools for local government planners. Can. J. Urban Res. 2015, 24, 1-23.

41. Born, B.; Purcel, M. Avoiding the Local Trap: Scale and Food Systems in Planning Research. J. Plan. Educ. Res. 2006, 26, 195-207. [CrossRef]

42. CBS. Regionale Economische Groei 2018 [Regional Economic Growth 2018]. Available online: https: //www.cbs.nl/nl-nl/maatwerk/2019/16/regionale-economische-groei-2018 (accessed on 23 March 2020).

43. van Dijk, W.; Jansma, J.E.; Sukkel, W.; Van Reuler, H.; Vermeulen, T.; Visser, A.J. Closing the Life Cycle of Phosphorus in an Urbanfood System: The Case Almere (NL); PPO: Wageningen, The Netherlands, 2017.

44. Roorda, C.; Buiter, M.; Rotmans, J.; Bentvelzen, M.; Tillie, N.; Keeting, R. Benchmark Almere Urban Development: The State of the Sustainable Art. An International Benchmark of Sustainable Urban Development; Dutch Research Institute for Transitions (DRIFT), Erasmus University: Rotterdam, The Netherlands, 2011.

45. Agricola, H. Benchmark Voedselregio's. Vergelijking van Het Agrocomplex Flevoland, Regio Food Valley, Regio Rivierenland, Agrifood Capital en Regio Venlo. Benchmark Food Regions, in Dutch; Wageningen Environmental Research: Wageningen, The Netherlands, 2019.

46. Vogelzang, T.; Smit, B.; Kuiper, P.; Gillet, C. Grond in Beweging. Ontwikkelingen in Het Grondgebruik in de Provincie Flevoland in de Periode tot 2025 en 2040. Developments in Land Use in the Province of Flevoland, in Dutch; Wageningen Economic Research: Wageningen, The Netherlands, 2019.

47. Sociale Atlas van Almere [Social Atlas of Almere]. Available online: https://www.almere.nl/over-almere/ feiten-en-cijfers/sociale-atlas-almere/ (accessed on 23 March 2020).

48. Crul, M. Super diversity versus assimilation: How complex diversity in majority-minority cities challenges the assumptions of assimilation. J. Ethn. Migr. Stud. 2016, 42, 54-68. [CrossRef]

49. Wertheim-Heck, S.C.O. De stad op het bord van het platteland [the city in the countryside]; Essay commissioned by the Agro Expert Council Flevoland; Aeres Hogeschool Almere: Almere, The Netherlands, 2019.

50. Wertheim-Heck, S.C.O. Everyday Fare. Promoting a Sustainable and Healthy Food System for the City; Inaugural Adress Aeres University of Applied Sciences Almere: Almere, The Netherlands, 2017.

51. The Growing Green Cities Principles Prepared for:The City of Almere. Available online: https://floriade. almere.nl/fileadmin/files/floriade/BL_I-1._The_GGC_Principles.pdf (accessed on 23 March 2020).

52. RIVM. Wat Ligt er op Ons Bord? Veilig, Gezond en Duurzaam eten in Nederland. Safe, Healthy and Sustainable Food in the Netherlands, in Dutch; Rapport 2016-0200; Rijksinstituut voor Volksgezondheid en Milieu: Bilthofen, The Netherlands, 2016.

53. Brons, A.; Oosterveer, P.; Wertheim-Heck, S.C.O. Feeding the melting pot: Inclusive strategies for the multi-ethnic city. 2020; submitted.

54. Jansma, J.E.; Veen, E.V.; Dekking, A.G.J.; Visser, A.J. Urban Agriculture: How to Create a Natural Connection between the Urban and Rural Environment in Almere Oosterwold (NL). In Proceedings of the REAL CORP 2013, Rome, Italy, 20-23 May 2013.

55. Schmitt, E.; Keech, D.; Maye, D.; Barjolle, D.; Kirwan, J. Comparing the Sustainability of Local and Global Food Chains: A Case Study of Cheese Products in Switzerland and the UK. Sustainability 2016, 8, 419. [CrossRef]

56. Janssen-Jansen, L.B. From Amsterdam to Amsterdam Metropolitan Area: A Paradigm Shift. Int. Plan. Stud. 2011, 16, 257-272. [CrossRef] 
57. Vijn, M.; Veen, E.V. Ondernemers en Vrijwilligers Samen in een Voedselinitiatief. de (on)Mogelijkheden van een Samenwerkingsverband van Boeren en Burgers; de Praktijk in Almere Entrepreneurs and Volunteers in Food Initiatives. The (im)Possibilities of Cooperation o Farmers and Civilians: Practices in Almere, in Dutch; Report 329; WUR Wetenschapswinkel: Wageningen, The Netherlands, 2016.

58. Ten Brug, L.; Wertheim-Heck, S.C.O.; Brons, A. Almeerse Voedselstromen [Food Flows in Almere, in Dutch]; Aeres Hogeschool Almere: Almere, The Netherlands, 2018.

(C) 2020 by the authors. Licensee MDPI, Basel, Switzerland. This article is an open access article distributed under the terms and conditions of the Creative Commons Attribution (CC BY) license (http://creativecommons.org/licenses/by/4.0/). 